\section{Synthetic Analgesics}

Aтtempts to prepare new analgesics have, for many years, been based almost exclusively on the morphine molecule, the peripheral groups of which may be modified considerably with relatively little effect on the biological activity. The synthetic drug 'Pethidine' (ethyl 4-phenyl-1-methylpiperidine-4-carboxylate) has several structural features in common with morphine, and there is a considerable body of evidence which relates analgesics of the piperidine type to the morphine model ${ }^{1-4}$. The recently discovered 'Amidone' (dl-2-dimethylamino-4: 4-diphenylheptan-5-one) is also a potent analgesic. We have examined three types of compound for analgesic, antispasmodic and local anæsthetic action. Although none of these compounds is closely related to morphine, several have an analgesic potency equivalent to or approaching that of 'Pethidine'.

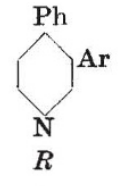

I

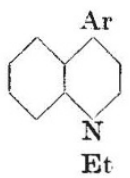

II

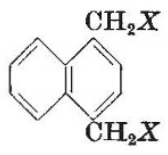

III
The synthesis of compounds of type I has already been reported ${ }^{5}$. Compounds of type II (in which $\mathrm{Ar}=\mathrm{Ph}$, or $p-\mathrm{MeO} . \mathrm{C}_{6} \mathrm{H}_{4}-$ ) have been prepared by hydrogenation of the oximes of ethyl $\beta$-(2-ketocyclo. hexyl)- $\beta$-arylpropionates, and the $p$-methoxy compound has also been demethylated to the correspond. ing $p$-hydroxy derivative ${ }^{6}$ The preparation of our compounds of type III has not previously been described. 1 :4-Bisdiethylaminomethylnaphthalene hydrochloride ( $X=-\mathrm{NEt}$ ) was obtained as colourless needles, m.p. 229-230 $0^{\circ}$ by condensing $1: 4$ bischloromethylnaphthalen $\theta^{7}$ with diethylamine. (Found: C, 63.3; H, 8.4; N, 7.0. $\mathrm{C}_{20} \mathrm{H}_{32} \mathrm{~N}_{2} \mathrm{Cl}_{2} \cdot \frac{1}{2} \mathrm{H}_{2} \mathrm{O}$ requires $\mathrm{C}, 63.1 ; \mathrm{H}, 8 \cdot 7$; $\mathrm{N}, 7 \cdot 3$ per cent. The picrate formed yellow needles, m.p. 203-204. Found: C, $50 \cdot 65 ; \mathrm{H}, 4 \cdot 6 ; \mathrm{N}, 14 \cdot 9 . \quad \mathrm{C}_{32} \mathrm{H}_{36} \mathrm{O}_{14} \mathrm{~N}_{8}$ requires C, $50.8 ; \mathrm{H}, 4 \cdot 8 ; \mathrm{N}, 14.8$ per cent.) $1: 4$-Bisisothiocarbamidomethylnaphthalene hydrochloride $\quad(X=$ $\left.-\mathrm{SC}(=\mathrm{NH}) \mathrm{NH}_{2}\right)$ was obtained as colourless plates, m.p. $270-272^{\circ}$, from the bischloromethyl compound and thiourea. (Found : C, 44.8; H, 4.6; N, 14.5. $\mathrm{C}_{14} \mathrm{H}_{18} \mathrm{~N}_{4} \mathrm{Cl}_{2} \mathrm{~S}_{2}$ requires $\mathrm{C}, 44.6 ; \mathrm{H}, 4.8 ; \mathrm{N}, 14.8$ per cent. The picrate formed yellow needles, m.p. 219-220. Found: C, 41.2; H, 3.0. $\mathrm{C}_{26} \mathrm{H}_{22} \mathrm{O}_{14} \mathrm{~N}_{10} \mathrm{~S}_{2}$ requires $\mathrm{C}, 41.0$; $\mathrm{H}, 2.9$ per cent.)

The L.D. ${ }_{50}$ in mgm./kgm. was determined by intraperitoneal injection in white mice. Of the N-alkyl$3: 4$-diarylpiperidines (type I), increase in the length of the alkyl chain decreased toxicity from 90 $\mathrm{mgm}$./kgm. for $3: 4$-diphenyl-1-methylpiperidine to $250 \mathrm{mgm}$. $/ \mathrm{kgm}$. for $3: 4$-diphenyl-1-n-butylpiperidine. In group II, 1-ethyl-4-( $p$-hydroxyphenyl)decahydroquinoline (120 mgm./kgm.) was less toxic than the unsubstituted 4-phenyl compound $(80 \mathrm{mgm}$./ $\mathrm{kgm}$.). In group III, the thiourea derivative (61 $\mathrm{mgm} . / \mathrm{kgm}$.) was much more toxic than the diethylamino derivative (370 mgm./kgm.). The Straub tail phenomenon was present in greater or less degree in mice poisoned with various members of each group. Compounds of types I and II mainly produced motor excitement (as does 'Pethidine'); group III was depressant.
TOXICITY AND ANALGESIC ACTIVITY

\begin{tabular}{|c|c|c|}
\hline Name & $\begin{array}{c}\text { Relative } \\
\text { analgesic } \\
\text { potency } \\
\text { (mice) }\end{array}$ & $\begin{array}{c}\text { L.D.so } \\
\text { (mgm./kgm.) } \\
\text { intraperitoneal } \\
\text { injection, mice }\end{array}$ \\
\hline 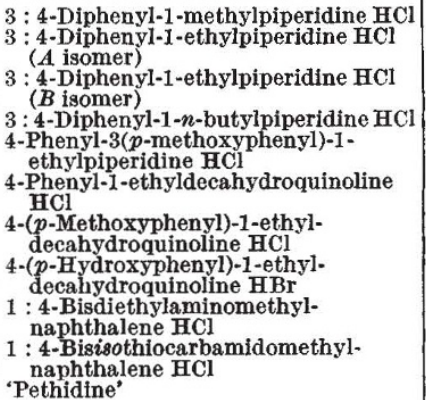 & $\begin{array}{l}\text { stimulant } \\
0 \cdot 6 \\
0 \\
0 \cdot 6 \\
0 \cdot 4 \\
0 \cdot 6 \\
0 \cdot 7 \\
0 \\
1 \cdot 0 \\
1 \cdot 0 \\
1 \cdot 0\end{array}$ & $\begin{array}{r}90 \\
100 \\
130 \\
250 \\
150 \\
81 \\
100 \\
120 \\
370 \\
61 \\
150\end{array}$ \\
\hline
\end{tabular}

Drugs in group I were irritant when placed in the conjunctival sac of rabbits, and neither group I nor group III showed any evidence of local anæsthetic properties. Group II drugs were less irritant than group I and had some effect as anæsthetics. The most powerful, 1-ethyl-4-( $p$-methoxyphenyl) decahydroquinoline, had a potency of 10 per cent of cocaine hydrochloride. The compounds were tested for antispasmodic activity against barium chloride (5 mgm.), histamine base (1 $\mu \mathrm{gm}$.$) , acetylcholine (1 \mu \mathrm{gm}$.$) in a$ $75 \mathrm{ml}$. bath. None of the compounds was highly specific, but all had some antispasmodic activity. Group I compounds were most active, $3: 4$-diphenyl1-ethylpiperidine having $1 / 33$ the activity of benadryl against spasm induced by histamine; against acetylcholine, 1/250 the activity of atropine sulphate ; against barium, $1 / 6$ the activity of 'Pavatrine'. Group II and group III were of a similar order of potency against barium-induced spasm, but much less active against histamine and acetylcholine. The analgesic potency was estimated according to the method of Davies et al..$^{8}$, except that mice were used instead of rats. Group III drugs were found to be equal in potency to 'Pethidine'. Groups I and II showed lesser and varying degrees of potency, and 3:4-diphenyll-methylpiperidine is a stimulant. The considerable analgesic activity of $1: 4$-bisdiethylaminomethylnaphthalene is of interest, as this is a new class of compound to exhibit pronounced activity.
G. M. BADGER*
J. W. COOK
G. M. S. Donald
J. D. P. Graham*
T. WALKER

Departments of Chemistry

and of Materia Medica,

University of Glasgow. March 24.

* I.C.I. Research Fellows.

${ }^{1}$ Schaumann, O., Arch. Exp. Path. Pharm., 196, 109 (1940).

${ }^{2}$ Jensen, K. A., and Lundquist, F., Dansk. Tidsskr. Farm., 17, 173 (1944).

${ }^{3}$ MacDonald, A. K., Woolfe, G., Bergel, F., Morrison, A. L., and Rinderknecht, H., Brit. $J$ Pharmacol., 1, 4 (1946).

- Foster, R. H. K., and Carman, A. J., J. Pharm. Exp. Ther., 91, 195 (1947).

s Barr, W., and Cook, J. W., J. Chem. Soc., 438 (1945).

- Badger, G. M., Cook, J. W., and Walker, T., J. Chem. Soc. (in the press).

'Badger, G. M., Cook, J. W., and Crosbie, G. W., J. Chem. Soc., 1432 (1947).

Davies, O. L., Raventos, J., and Walpole, A. L., Brit. J. Pharmacol., 1, 255 (1946). 